\title{
Teachers' Mathematics Knowledge for Teaching Early Algebra: A Systematic Review from the MKT Perspective
}

\author{
Nataly Pincheira * D and Ángel Alsina (D) \\ Department of Subject-Specific Didactics, Faculty of Education and Psychology, University of Girona, \\ 17004 Girona, Spain; angel.alsina@udg.edu \\ * Correspondence: nataly.pincheira@udg.edu
}

check for updates

Citation: Pincheira, N.; Alsina, Á. Teachers' Mathematics Knowledge for Teaching Early Algebra: A Systematic Review from the MKT Perspective. Mathematics 2021, 9, 2590. https:/ / doi.org/10.3390/math9202590

Academic Editor: Luis Carlos Contreras-González

Received: 22 September 2021

Accepted: 13 October 2021

Published: 15 October 2021

Publisher's Note: MDPI stays neutral with regard to jurisdictional claims in published maps and institutional affiliations.

Copyright: (c) 2021 by the authors. Licensee MDPI, Basel, Switzerland. This article is an open access article distributed under the terms and conditions of the Creative Commons Attribution (CC BY) license (https:/ / creativecommons.org/licenses/by/ $4.0 /)$.

\begin{abstract}
The mathematical knowledge for teaching (MKT) model emerged from the advances proposed by Shulman in 1986 and 1987 as part of the teacher's professional knowledge model, and refers to the mathematical knowledge that the teacher employs to carry out the instruction process in the classroom. MKT has become an international benchmark for research into mathematics education and boasts a great scope and impact to date. The objective of this study is to conduct a systematic review of the way in which the MKT of early algebra teachers has been conceptualized and empirically studied in the scientific literature from 2010 to 2021. A systematic search in the Web of Science and Scopus databases led to a review of 17 papers. The results show great advances in the conceptualization of mathematical knowledge for teaching early algebra, focusing mainly on primary education teachers and on specialized knowledge of the content. In turn, there is a predominance of studies that address functional thinking as a content area. We conclude that more empirical studies are needed that address the mathematical knowledge that childhood and primary education teachers have of early algebra.
\end{abstract}

Keywords: mathematical knowledge; teachers; systematic review; early algebra; childhood and primary education

\section{Introduction}

The professional knowledge of teachers has been a topic of interest in the field of mathematics education in recent decades [1]. Llinares [2] notes that the research agenda into mathematics education on the professional development of teachers is very prolific (e.g., $[3,4]$ ), since it positively impacts the quality of teaching and the performance of students [5,6]. According to Chapman [7], "it is not only important what mathematics teachers know but also how they know it and what they are able to mobilize for teaching" (p. 295). The latter has brought with it the development of research on the knowledge of mathematics teachers [8], approached from different specific themes, such as problemsolving (e.g., [9]), geometry (e.g., [10]), and others.

The review of a series of studies on the learning and knowledge of pre-service mathematics teachers carried out by Ponte and Chapman [11] highlights the Mathematical Knowledge for Teaching (MKT) proposed by Ball, Thames and Phelps [12] defined as "the mathematical knowledge that teachers uses in the classrooms to produce instruction and student growth" [13] (p. 374). As a result, the theoretical tools provided by the model have expanded in scope and created a large impact on the research community.

In this context, the need arises to understand the characteristics of the mathematical knowledge required by teachers to meet the challenges and demands posed by today's childhood (three to six years old) and primary education (six to twelve years old) curricula (e.g., $[14,15])$, as in the case of early algebra, by incorporating knowledge of an algebraic nature from the first levels of schooling as an additional content standard [16].

Early algebra responds to a new proposal for curricular change [17] in order to integrate modes of algebraic thinking from the initial stages of schooling $[18,19]$, a process 
that Kaput [20] refers to as the algebrization of the curriculum, which implies it "would empower students, particularly by fostering a greater degree of generality in their thinking and an increased ability to communicate that generality" [21] (p. 58).

The development of early algebra has been reflected mainly in studies with childhood and primary education students (e.g., [22-25]). However, it is essential to analyze experiences that involve the teachers who educate these students [26], since they are essential to implementing the change to early algebra teaching from the first years of schooling.

Consequently, considering the importance and role of teacher knowledge in student learning [27] and the potential for the development of algebraic thinking in the first years of schooling, it is necessary to pay attention to mathematical knowledge for teaching. This requires knowing the contributions of the studies and literature that have supported the development of this research agenda.

Strand and Mills [28] conducted a review of the literature from 1998 to 2012 on the knowledge of mathematical content for teaching early algebra in primary education, analyzing 21 research papers. The results show that primary education teachers exhibit procedural skills for determining patterns. However, they have problems interpreting algebraic symbols, graphical representations and solving algebraic problems. Our intention is to continue investigating in this direction to provide updated data that can be used to investigate the advances made in the conceptualization of MKT for early algebra, the goal being to offer a general panorama that comprises a framework of empirical knowledge and challenges to address in future research.

The objective of our study is to conduct a systematic review of the way in which the MKT of Early Algebra teachers has been conceptualized and empirically studied in scientific production from 2010 to 2021. To do so, we will analyze general aspects of each scientific production, such as: author(s), year and country in which the research was carried out, and objectives. We will then focus on more specific aspects, such as the domains and subdomains of the MKT model that is addressed, specific areas of algebraic content, the nature of the participants, research method and the main results that are presented.

\section{Mathematical Knowledge for Teaching (MKT)}

The contributions of Shulman [29] on teacher knowledge reveal the importance of content knowledge for teaching, defined as "the amount and organization of knowledge per se in the mind of the teacher" (p. 9), and pedagogical knowledge as "the particular form of content knowledge that embodies the aspect of content most germane to its teachability" (p. 9). This has given way to the study and development of other models derived from Shulman's $[29,30]$ in this area specific for mathematics teachers [12,31-33], showing that content knowledge is more effective in teaching when it is combined with pedagogical knowledge [8,34].

Ball et al. [12], based on the knowledge framework proposed by Shulman [29,30], identified the essential elements of knowledge to teach mathematics and developed the mathematical knowledge for teaching (MKT) model, described as "the mathematical knowledge needed to carry out the work of teaching mathematics" [12] (p. 395).

Based on an analysis of teacher practices, Ball et al. [12] determined the mathematical demands of teaching that would later make up the model's components, providing an empirical basis for the positive relationship that constitutes the pedagogical knowledge of teachers and the learning outcomes of students. Accordingly, the MKT model establishes a domain map of mathematical knowledge for teaching that considers content knowledge and pedagogical content knowledge.

Content knowledge is subdivided into three aspects: common content knowledge (CCK), which refers to the "mathematical knowledge and skill used in settings other than teaching" [12] (p. 399), meaning it corresponds to the knowledge that can be achieved throughout the educational levels and that anyone who faces a mathematical task possesses; specialized content knowledge (SCK), which refers to "mathematical knowledge and skill unique to teaching" [12] (p. 400), meaning knowledge that is specific to the teacher and that 
is used to engage in teaching tasks related to "how to accurately represent mathematical ideas, provide mathematical explanations for common rules and procedures, and examine and understand unusual solution methods to problems" [13] (pp. 377-378); and knowledge of the mathematical horizon, which is defined as "awareness of how mathematical topics are related over the span of mathematics included in the curriculum" [12] (p. 403), meaning the knowledge that allows the teacher to establish the way in which the mathematical contents are related to other contents of the curriculum.

A pedagogical knowledge of the content considers: the knowledge of the content and the students (KCS), which is defined as the "content knowledge intertwined with knowledge of how students think about, know, or learn this particular content" [13] (p. 375), i.e., it is the knowledge that the teacher has about the knowledge of the students, letting the teacher predict situations and anticipate the concerns, attitudes or difficulties of the students; knowledge of content and teaching (KCT), "combines knowledge about teaching and knowing about mathematics" [12] (p. 401), meaning knowledge that integrates specific mathematical knowledge and pedagogical and didactic aspects of the teaching processes involved in student learning; and, finally, knowledge of the curriculum, "represented by the full range of programs designed for the teaching of particular subjects and topics at a given level, and the variety of instructional materials available in relation to those programs" [12] (p. 391) meaning it refers to the orientations and approaches corresponding to the study programs designed for each educational level in the area of mathematics, together with the instructional materials.

The theoretical implications provided by the MKT model [13] allow us to categorize the knowledge that a teacher must manifest during the exercise of their teaching practice to teach mathematics.

\section{Early Algebra}

The teaching of early algebra in childhood and primary education has been consolidated in recent years, as there is a growing consensus of researchers to provide learning experiences that promote the development of algebraic thinking from the earliest levels [35-38].

Early algebra seeks to promote thinking habits in classrooms that reflect the structure that underlies mathematics [35]. That is, it concerns a way of thinking and acting with mathematical objects, relationships, structures and situations to promote teaching that is grounded in mathematics [39].

Incorporating algebra early in childhood and primary education requires accommodating a broad conception of algebra in order to achieve the development of algebraic thinking. According to the literature, the understanding of patterns, number relationships and functions are some of the fundamental elements that contribute to this process $[40,41]$.

Papic, Mulligan, and Mitchelmore [24] note that algebraic thinking starts to develop in the childhood education stage through the process of generalization. Carraher, Martínes, and Schliemann [42] state that to address mathematical generalization, it is necessary to start by identifying mathematical patterns and relationships. In this way, patterns contribute to the development of mathematical representation and abstraction and provide an essential foundation for the development of early algebraic thinking [43].

Therefore, generalization and the search for regularities form a central aspect in the development of algebraic thinking in the early years [44].

Along these same lines, Kaput [45] notes that algebraic thinking develops from an awareness of the structural relationships of arithmetic patterns and structure, suggesting three basic areas of algebraic content: generalized arithmetic, functional thinking, and the application of generalizations as a modeling language.

Generalized arithmetic refers to the relationships between numbers, the properties of operations, the equal sign, equivalence, and variables. By developing this line of content, students can understand the properties of numbers and their operations, and thus perform calculations and analyze how the operations are related to one another [46,47]. In turn, 
students are expected to use variable notation in a meaningful way to represent arithmetic properties, expressions, and equations [48].

Functional thinking considers the generalization of the relationships between covariable quantities, numerical and figurative patterns, functions, and algebraic expressions. On the one hand, students gradually learn to determine patterns, describe the change in a sequence of values, and identify how two quantities co-vary [46]. On the other hand, functional thinking promotes the algebraic activity linked to the process of generalization and of representing relationships between quantities [49].

Generalization as a modeling language refers to the description of regularities that occur implicitly during the development of mathematical situations or phenomena. This area of content allows students to identify regularities and select appropriate models for solving various mathematical situations.

Finally, another of the key elements to promote algebraic thinking that stands out in the literature is relational thinking. This refers to the structural sense of the relationships between the elements of an arithmetic expression and the properties of operations [23,50].

\section{Methodology}

In keeping with our study objective, we relied on a systematic review methodology [51], which is an explicit and replicable search strategy with studies based on predetermined criteria [52]. In our case, the studies involved the mathematical knowledge of childhood and primary education instructors for teaching early algebra.

When conducting the research, we considered the criteria and procedures of the quality standards of the PRISMA (Preferred Reporting Items for Systematic reviews and Meta-Analyses) statement, proposed by Urrutia and Bonfill [53] for systematic reviews, such as: eligibility criteria, sources of information, search and selection of studies, data extraction process, listing of data, and summary of results.

The following phases were employed to carry out the systematic review:

Phase 1. Establish the search elements

The search elements were formulated from the key terms that guide our study. To establish the concepts, three central ideas were considered: the knowledge of the teachers as per the MKT model, the main content areas from early algebra taken from the literature, and the teacher participants considered in the study. These concepts generated the search elements, as shown in Table 1.

Table 1. Search elements.

\begin{tabular}{cc}
\hline Key Terms & Concepts \\
\hline Teacher knowledge & Mathematical knowledge for teaching \\
& Teacher knowledge \\
\hline & Algebra \\
Content areas derived from early algebra & Algebraic reasoning "OR" algebraic thinking \\
& Pattern generalization \\
& Functional thinking \\
\hline \multirow{2}{*}{ Participants } & Primary teacher \\
& Elementary teacher \\
& Early childhood teacher \\
\hline
\end{tabular}

Phase 2. Select the sources of information

For the source of information, we consulted databases that include scientific production on an international level that is more relevant in the field of educational research, such as: Web of Science (WOS) by Clarivate Analytics, and Scopus by Elsevier, given the index of impact they constitute (JCR and SJR, respectively), and the implication of the indexing of scientific articles in journals that fall under these parameters.

Phase 3. Establish eligibility (inclusion and exclusion) criteria 
The following inclusion criteria were established: (a) academic papers, as we want to ensure that only papers published in scientific journals that have undergone a rigorous peerreview process are considered; (b) publications in English since it is the universal language of scientific research, Spanish because it is the authors' first language, or Portuguese to ensure a greater geographic range of studies; (c) publication period 2010-2021; and (d) full text of the papers available for review.

The exclusion criteria were as follows: (a) book chapters, conference proceedings, books or other types of publications; (b) access to the publication restricted or not available for review; (c) bibliographic and editorial reviews, duplicate papers, or other systematic reviews; (d) papers in languages other than English, Spanish, or Portuguese; (e) papers whose structure does not allow for the analysis proposed, such as essays, reviews, etc.

Phase 4. Data extraction and processing to establish the sample

The data were extracted and processed in May 2021, as follows: (1) an initial search was carried out in the databases by combining the key concepts established in the initial phase using the "AND" connector. The key concepts were applied to the title of the paper, the abstract and keywords; (2) the inclusion and exclusion criteria were applied to the academic papers that were filtered by the search engines; and (3) the results were filtered by a language review, followed by title review. If the title of the paper did not provide sufficient clarity to apply these criteria, the abstracts were reviewed. Finally, the papers were filtered for duplicates to yield the study sample.

\subsection{Sample}

The search process allowed us to establish the study sample, consisting of 17 academic papers that constitute our analysis units, as seen in Figure 1.

\begin{tabular}{|c|c|c|}
\hline \multirow[b]{2}{*}{ Databases } & \multicolumn{2}{|c|}{ Search for articles } \\
\hline & Web of Science & Scopus \\
\hline Articles with syntax applied & 159 & 122 \\
\hline Articles filtered by language & 126 & 115 \\
\hline Articles filtered by title & 48 & 51 \\
\hline Articles filtered by abstract & 6 & 17 \\
\hline Articles filtered for duplication & 6 & 11 \\
\hline Total selected articles & 1 & \\
\hline
\end{tabular}

Figure 1. Methodological outline of the PRISMA-type systematic review process.

The papers selected, published between 2010 and 2021, correspond to empirical studies (quantitative and/or qualitative) based on the MKT of early childhood and primary education teachers involving early algebra.

\subsection{Analysis Categories}

To address our study objective, we defined a series of categories that allowed us to consider and delve into the analysis of the selected scientific productions on the MKT for early algebra. The analysis categories established were: (a) author(s), year and country in which the study was conducted, which can be used to place each paper chronologically and geographically; (b) research goal; (c) domains and subdomains of the MKT model measured by the research; (d) area of algebraic content detailed in the research; (e) the nature of the participants; (f) research method used to investigate the MKT; and ( $g$ ) the main findings presented. 


\subsection{Data Analysis}

Having established the sample, the data were analyzed by reading each research paper exhaustively. To this end, the analysis categories established were applied using the content analysis technique [54], and the information was recorded and encoded in a data analysis template made using Excel. This last step made it possible to carry out a descriptive analysis of the data by preparing analysis tables for the qualitative information extracted from the review of the selected paper. Initially, a vertical analysis, or analysis within the case [55], was carried out of each of the 17 research papers that constitute our analysis unit in order to obtain a general categorization of each study. We then conducted a horizontal or cross-sectional analysis [55], which established comparisons between the research papers that make up the sample to search for systematic similarities and differences.

It should be noted that the data coding work considered a process of successive cyclical and inductive reviews of the research articles that make up the study sample. This process was carried out by the first author, and was supervised and reviewed by the second author.

\section{Results}

The results of our study consider the analysis of 17 research papers published between 2010 and 2021 that investigate the mathematical knowledge of early childhood and primary education teachers for teaching early algebra from the perspective of the MKT model.

\subsection{Categorization of the Papers That Analyze Mathematical Knowledge for Teaching Early Algebra}

For the selected articles, we identified the country in which the research was carried out and the objective of the study. The latter will give us an insight into the conceptualization of MKT for early algebra by identifying the intentions that spurred each research effort. We subsequently identified the nature of the participants corresponding to the teaching staff who are the subject of study, be it early childhood or primary education, pre-service or in service.

Finally, we have coded the domains and subdomains of the MKT model to which they correspond, namely: common content knowledge (CCK), specialized content knowledge (SCK), mathematical horizon knowledge (MHK), knowledge of content and students (KCS), knowledge of content and teaching (KCT), and knowledge of the curriculum (CK), as shown in Table 2.

The selected studies took place mainly in the United States, followed by Australia and Brazil. It should be noted that only one study was found involving collaboration between two countries (Spain-Portugal).

In terms of the conceptualization of mathematical knowledge, we observed a preference for conducting research aimed at understanding the mathematical knowledge that teachers demonstrate for teaching a specific area of algebraic content (around three-fourths of the studies analyzed).

An incipient number of studies (about a quarter) investigates professional development and its effect on teaching based on the mathematical knowledge that educators demonstrate when teaching early algebra. Finally, there is only one study that proposes developing an instrument to measure the mathematical knowledge of teachers, more specifically, pedagogical knowledge.

Regarding the nature of the participants, more than two-thirds of the studies involved mainly primary education teachers, of whom three were pre-service teachers and ten in-service. A low number of studies involved early childhood education teachers, whether pre-service or in-service.

Of note is the fact that only two of the seventeen studies address both types of participants, both early childhood education and primary teachers, pre-service. 
Table 2. Categorization of the papers (2010-2021) on the MKT for teaching early algebra.

\begin{tabular}{|c|c|c|c|c|c|c|c|c|c|c|c|}
\hline \multirow{2}{*}{ Author(s)/Country } & \multirow{2}{*}{ Objective } & \multirow{2}{*}{$\begin{array}{l}\text { Early Childhood } \\
\text { Education Teachers }\end{array}$} & \multirow{2}{*}{$\begin{array}{l}\text { Primary Education } \\
\text { Teachers }\end{array}$} & \multirow{2}{*}{ Pre-Service } & \multirow{2}{*}{ In Service } & \multicolumn{3}{|c|}{ Content Knowledge } & \multicolumn{3}{|c|}{ Pedagogical Knowledge of the Conten } \\
\hline & & & & & & CCK & SCK & MHK & KCS & КСТ & CK \\
\hline $\begin{array}{l}\text { Bair and Rich [56], } \\
\text { United States }\end{array}$ & $\begin{array}{c}\text { Characterize the development of specialized } \\
\text { knowledge for teaching algebraic reasoning and } \\
\text { number theory. }\end{array}$ & $\mathrm{x}$ & $\mathrm{x}$ & $x$ & & & $\mathrm{x}$ & & & & \\
\hline $\begin{array}{l}\text { Dash et al. [57], } \\
\text { United States * }\end{array}$ & $\begin{array}{l}\text { Investigate the effects of professional development } \\
\text { on the pedagogical content and practices of } \\
\text { fifth-grade teachers. }\end{array}$ & & $\mathrm{x}$ & & $\mathrm{x}$ & & & & & & \\
\hline $\begin{array}{l}\text { McAuliffe and } \\
\text { Lubben [58], South } \\
\text { Africa }\end{array}$ & $\begin{array}{l}\text { Examine the content knowledge of a teacher } \\
\text { pre-service for teaching early algebra. }\end{array}$ & & $\mathrm{x}$ & $\mathrm{x}$ & & & $\mathrm{x}$ & & & & \\
\hline Wilkie [59], Australia & $\begin{array}{l}\text { Analyze the mathematical knowledge of Primary } \\
\text { Education teachers for teaching functional thinking. }\end{array}$ & & $\mathrm{x}$ & & $\mathrm{x}$ & & $\mathrm{x}$ & & $\mathrm{x}$ & $\mathrm{x}$ & $\mathrm{x}$ \\
\hline $\begin{array}{l}\text { Trivilin and } \\
\text { Ribeiro [60], Brazil }\end{array}$ & $\begin{array}{l}\text { Understand what knowledge teachers announce } \\
\text { and demonstrate involving the different meanings } \\
\text { of the equal sign. }\end{array}$ & & $\mathrm{x}$ & & $\mathrm{x}$ & $\mathrm{x}$ & $\mathrm{x}$ & & & & $\mathrm{x}$ \\
\hline $\begin{array}{l}\text { Wilkie and } \\
\text { Clarke [61], Australia }\end{array}$ & $\begin{array}{l}\text { Analyze the perspectives of late primary school } \\
\text { teachers involving their knowledge and practice of } \\
\text { algebra. }\end{array}$ & & $\mathrm{x}$ & & $\mathrm{x}$ & & & & $\mathrm{x}$ & $\mathrm{x}$ & \\
\hline $\begin{array}{l}\text { Kosko [62], United } \\
\text { States ** }\end{array}$ & $\begin{array}{l}\text { Explore whether elementary teachers chose probing } \\
\text { questions, given two hypothetical math lesson } \\
\text { scenarios. }\end{array}$ & & $\mathrm{x}$ & & $\mathrm{x}$ & & & & & & \\
\hline $\begin{array}{l}\text { Di Bernardo } \\
\text { et al. [64], Italy }\end{array}$ & $\begin{array}{l}\text { Access the knowledge of future teachers to } \\
\text { recognize and interpret student output in the } \\
\text { context of algebraic thinking. }\end{array}$ & $\mathrm{x}$ & $\mathrm{x}$ & $\mathrm{x}$ & & $\mathrm{x}$ & $\mathrm{x}$ & & & & \\
\hline $\begin{array}{l}\text { Ferreira, Ribeiro and } \\
\text { Ribeiro [65], Portugal }\end{array}$ & $\begin{array}{l}\text { Identify and discuss the MKT revealed by a group } \\
\text { of teachers when discussing tasks aimed at } \\
\text { improving algebraic thinking. }\end{array}$ & & $\mathrm{x}$ & & $\mathrm{x}$ & $\mathrm{x}$ & $\mathrm{x}$ & & $\mathrm{x}$ & & \\
\hline $\begin{array}{l}\text { Zapatera and } \\
\text { Callejo [66], Spain }\end{array}$ & $\begin{array}{l}\text { Study the relationship between mathematical } \\
\text { knowledge and teaching skills in the context of } \\
\text { pattern generalization. }\end{array}$ & & $\mathrm{x}$ & $\mathrm{x}$ & & $\mathrm{x}$ & $\mathrm{x}$ & & & & \\
\hline $\begin{array}{l}\text { Heck et al. [67], } \\
\text { United States }\end{array}$ & $\begin{array}{l}\text { Examine the learning outcomes of teachers when } \\
\text { they participate in different formats of professional } \\
\text { learning experience courses to teach early algebra. }\end{array}$ & & $\mathrm{x}$ & & $\mathrm{x}$ & $\mathrm{x}$ & & & $\mathrm{x}$ & & \\
\hline
\end{tabular}


Table 2. Cont

\begin{tabular}{|c|c|c|c|c|c|c|c|c|c|c|c|}
\hline \multirow{2}{*}{ Author(s)/Country } & \multirow{2}{*}{ Objective } & \multirow{2}{*}{$\begin{array}{l}\text { Early Childhood } \\
\text { Education Teachers }\end{array}$} & \multirow{2}{*}{$\begin{array}{l}\text { Primary Education } \\
\text { Teachers }\end{array}$} & \multirow{2}{*}{ Pre-Service } & \multirow{2}{*}{ In Service } & \multicolumn{3}{|c|}{ Content Knowledge } & \multicolumn{3}{|c|}{ Pedagogical Knowledge of the Content } \\
\hline & & & & & & CCK & SCK & MHK & KCS & КСТ & CK \\
\hline $\begin{array}{l}\text { Noviyanti and } \\
\text { Suryadi [68], } \\
\text { Indonesia }\end{array}$ & $\begin{array}{l}\text { Analyze the basic mathematical knowledge of Early } \\
\text { Childhood Education teachers. }\end{array}$ & $\mathrm{x}$ & & & $\mathrm{x}$ & $\mathrm{x}$ & $\mathrm{x}$ & & & & \\
\hline $\begin{array}{l}\text { Gasteiger et al. [69], } \\
\text { Germany * }\end{array}$ & $\begin{array}{l}\text { Propose an instrument to measure the pedagogical } \\
\text { knowledge of the mathematical content of Early } \\
\text { Childhood Education teachers from a cognitive } \\
\text { perspective and from a situated. }\end{array}$ & $\mathrm{x}$ & & $\mathrm{x}$ & $\mathrm{x}$ & & & & & & \\
\hline $\begin{array}{l}\text { Souza, Ribeiro and } \\
\text { Pazuch [70], Brazil }\end{array}$ & $\begin{array}{l}\text { Identify how professional learning tasks, based on } \\
\text { teaching practice, contribute to the mobilization } \\
\text { and expansion of the algebraic thinking of Primary } \\
\text { Education teachers, in relation to the different } \\
\text { meanings of the equal sign. }\end{array}$ & & $\mathrm{x}$ & & $\mathrm{x}$ & & $\mathrm{x}$ & & $\mathrm{x}$ & $\mathrm{x}$ & \\
\hline $\begin{array}{l}\text { Oliveira, Polo-Blanco } \\
\text { and Henríquez [71], } \\
\text { Spain-Portugal }\end{array}$ & $\begin{array}{l}\text { Understand what aspects of functional thinking are } \\
\text { exhibited by future Spanish and Portuguese } \\
\text { Primary Education teachers at the beginning of } \\
\text { their teacher training program. }\end{array}$ & & $\mathrm{x}$ & $\mathrm{x}$ & & & $\mathrm{x}$ & & & & \\
\hline $\begin{array}{l}\text { Souza, Pazuch and } \\
\text { Ribeiro [72], Brazil }\end{array}$ & $\begin{array}{l}\text { Understand how the construction of mathematical } \\
\text { and didactic knowledge of teachers who teach } \\
\text { primary school mathematics occurs about the } \\
\text { different meanings of the equal sign. }\end{array}$ & & $\mathrm{x}$ & & $\mathrm{x}$ & $\mathrm{x}$ & $\mathrm{x}$ & $\mathrm{x}$ & $\mathrm{x}$ & $\mathrm{x}$ & \\
\hline
\end{tabular}

${ }^{*}$ Refers to pedagogical knowledge without specifying a subdomain. ${ }^{* *}$ Does not refer to a specific subdomain. 
When comparing the studies, we see that the majority involve both content knowledge and pedagogical content knowledge, which implies delving into more than one subdomain of mathematical knowledge (MKT). In other words, the research allows inquiring into various aspects of the mathematical knowledge and teacher classroom instruction for teaching early algebra (for example, solving and interpreting an algebraic task, identifying teaching strategies, understanding possible student errors, among others).

Moreover, if we consider the conceptualization of MKT, almost all of the studies inquire into specialized content knowledge (SCK), while only half of these inquire into common content knowledge (CCK) and knowledge of content and students (KCS). There is a lower proportion of studies that inquire into the knowledge of content and teaching (about a quarter). Finally, less than a quarter of the research we analyzed addressed the subdomains of knowledge of the curriculum and the mathematical horizon.

To investigate the different subdomains of the MKT model, the studies analyzed the essential aspects that characterize them, as described below:

In general, the studies that delve into common content knowledge (CCK) involve teachers directly in solving mathematical tasks in an early algebra content area: for example, the representation of equality in mathematical expressions (e.g., $[60,70])$; solving firstdegree equation problems (e.g., [64,67]); or the generalisation of patterns (e.g., [66]). These studies show a lack of mastery of algebraic content and reasoning, difficulties in recognising the different mathematical meanings of the equal sign and difficulties in obtaining the general rule of a growth pattern.

Regarding the subdomain of specialized content knowledge (SCK), the studies focus on aspects of knowledge typical of teachers. Bair and Rich [56], for example, investigate the ability of teachers to explain and justify mathematical ideas that involve the development of algebraic thinking. McAuliffe and Lubben [58] focus on the explanations provided by teachers regarding the selection of examples, representations, and modifications of an algebraic task. Wilkie $[59,63]$ and Wilkie and Clarke [61] consider the possible correct answers that teachers provide to questions that arise over the course of a certain algebraic task, and they identify recursive and explicit generalization strategies.

Bair and Rich [56] show that teachers can make progress in analyzing specific aspects of an algebraic task by identifying and discussing the concepts involved in the task after its completion. McAuliffe and Lubben [58] report good knowledge of representations for teaching patterns (use of concrete manipulatives, function tables and flowcharts), while explanations about the selection of examples to describe the relationships leading to generalization are not always considered successful. Wilkie $[59,63]$ and Wilkie and Clarke [61] find that teachers can identify strategies for generalizing a linear growth pattern, but have difficulties in representing the generalizations symbolically.

The studies by Di Bernardo et al. [64], Trivilin and Ribeiro [60], Souza, Ribeiro and Pazuch [70], Oliveira, Polo-Blanco, and Henríquez [71] focus on how teachers interpret the processes of solving an algebraic task or algebraic content area. Evidence has been found of difficulties in assigning the semantic meaning involved in solving a task, such as the meaning of division in the performance of an equal sharing task (e.g., [64]), the meaning of equivalence of the equal sign in a mathematical expression (e.g., $[60,70])$ and difficulties in interpreting variables, relationships between variables, and connections between function representations (e.g., [71]).

Ferreira, Ribeiro, and Ribeiro [65] consider how teachers understand and identify a mathematical situation that contains an error, especially the source and the reasons that lead to the occurrence of this error [72]. Finally, Zapatera and Callejo [66] focus on identifying significant mathematical elements that are evident in the performance of an algebraic task.

The study conducted by Souza, Pazuch, and Ribeiro [72] investigates the knowledge of the mathematical horizon through the relationships that teachers establish involving relational thinking in early school years and its impact on later school years.

By contrast, studies that delve into the subdomain of knowledge of content and students (KCS), such as the study by Wilkie [59], focus on how teachers understand the 
possible errors that students can make when performing an algebraic task. The studies carried out by Wilkie [63], Ferreira, Riberiro, and Ribeiro [65], Souza, Ribeiro, and Pazuch [70], and Souza, Pazuch, and Ribeiro [72] analyze situations that allows teachers to anticipate what the students think and the difficulties they may experience in an algebraic task.

The studies that consider the subdomain of knowledge of content and teaching (KCT) address how teachers identify suitable teaching strategies for exploring functional relationships $[59,61]$, and examples of learning experiences appropriate for the development of algebraic thinking $[63,70,72]$.

The subdomain of knowledge of the curriculum is covered in the studies undertaken by Wilkie [59] and Wilkie [63] when inquiring into teachers' understanding of the curriculum and its impact on decision-making involving learning experiences related to early algebra. Trivilin and Ribeiro [60] study how teachers approach the inclusion of the meanings of the equal sign in the curriculum.

\subsection{Areas of Algebraic Content and Research Method Used to Investigate the MKT for Early Algebra}

Table 3 shows the area of mathematical content that the studies in our data set address, the level of schooling in which they focus in order to investigate the mathematical knowledge, as well the number of participants $(N)$ present in each study and the research method used to inquire into the mathematical knowledge of early childhood and primary education teachers involving the teaching of early algebra.

Table 3. Areas of mathematical content addressed in the studies and research methods used to investigate mathematical knowledge for teaching early algebra.

\begin{tabular}{|c|c|c|c|c|c|c|c|c|c|c|}
\hline Studies & $\begin{array}{l}\text { Area of } \\
\text { Content }\end{array}$ & $\begin{array}{c}\text { Early } \\
\text { Childhood } \\
\text { Education }\end{array}$ & $\begin{array}{l}\text { Primary } \\
\text { Education }\end{array}$ & $N$ & Questionnaire & Survey & Interview & Class Obs. & Meeting & $\begin{array}{l}\text { Documentary } \\
\text { Records }\end{array}$ \\
\hline Bair and Rich [56] & $\mathrm{AR} / \mathrm{T}$ & $x$ & $x$ & $>5000$ & & & & & & $x$ \\
\hline Dash et al. [57] & $\mathrm{AR} / \mathrm{T}$ & & $x$ & 79 & $x$ & & & & & \\
\hline $\begin{array}{l}\text { McAuliffe and } \\
\text { Lubben [58] }\end{array}$ & FT & & $x$ & 1 & & & & $\mathrm{x}$ & & \\
\hline Wilkie [59] & FT & & $x$ & 105 & $x$ & & & & & \\
\hline Trivilin and & RT & & $x$ & 10 & $\mathrm{x}$ & & $\mathrm{x}$ & & & \\
\hline Wilkie and Clarke [61] & FT & & $x$ & 10 & $\mathrm{x}$ & & $\mathrm{x}$ & & & $\mathrm{x}$ \\
\hline Kosko [62] & FT & & $\mathrm{x}$ & 45 & & $\mathrm{x}$ & & & & \\
\hline Wilkie [63] & FT & & $\mathrm{x}$ & 10 & $\mathrm{x}$ & $\mathrm{x}$ & & $\mathrm{x}$ & & \\
\hline Di Bernardo et al. [64] & $\mathrm{AR} / \mathrm{T}$ & $x$ & $\hat{x}$ & 60 & $\hat{x}$ & & & & & \\
\hline $\begin{array}{c}\text { Ferreira, Ribeiro and } \\
\text { Ribeiro [65] }\end{array}$ & GA & & $x$ & 14 & & & & & $x$ & $\mathrm{x}$ \\
\hline $\begin{array}{l}\text { Zapatera and } \\
\text { Callejo [66] }\end{array}$ & FT & & $x$ & 40 & $\mathrm{x}$ & & & & & \\
\hline Heck et al. [67] & $\mathrm{AR} / \mathrm{T}$ & & $x$ & 205 & $x$ & & & & $x$ & \\
\hline $\begin{array}{l}\text { Noviyanti and } \\
\text { Survadi [68] }\end{array}$ & FT & $\mathrm{x}$ & & 35 & & & $\mathrm{x}$ & $\mathrm{x}$ & & \\
\hline Gasteiger et al. [69] ** & FT & $x$ & & 149 & $x$ & & & & & \\
\hline $\begin{array}{l}\text { Souza, Ribeiro and } \\
\text { Pazuch [70] }\end{array}$ & RT & & $\mathrm{x}$ & 6 & $\hat{x}$ & & & & $\mathrm{x}$ & \\
\hline $\begin{array}{l}\text { Oliveira, Polo-Blanco } \\
\text { and Henríquez [71] }\end{array}$ & FT & & $\mathrm{x}$ & 164 & $\mathrm{x}$ & & & & & \\
\hline $\begin{array}{c}\text { Souza, Pazuch and } \\
\text { Ribeiro [72] }\end{array}$ & RT & & $x$ & 6 & & & & & $\mathrm{x}$ & $\mathrm{x}$ \\
\hline
\end{tabular}

${ }^{*}$ Number sense (patterns), Geometry and Measurement. ${ }^{* *}$ Numbers, Magnitudes and Patterns. ${ }^{* * *} 94$ pre-service teachers from Spain and 70 from Portugal.

The content areas considered for the analysis are those explicitly declared in the studies, such as: algebraic reasoning or thinking (AR/T), generalized arithmetic (GA), functional thinking (FT), and relational thinking (RT).

There is a greater predominance of studies that involve functional thinking, and more specifically, the development of patterns and functions. They are followed by studies that focus on general algebraic reasoning or algebraic thinking. A lower number of studies address relational thinking and the generalization of arithmetic.

Now, if we look at the levels of schooling, we notice that the contextualized studies in early childhood education focus on the development of algebraic thinking, and more specifically on functional thinking through patterns. While in primary education, the 
content areas are expanded, reaching the development of generalized arithmetic and relational thinking.

Another important aspect to note is that two of the studies that focus on early childhood education (e.g., [68,69]) propose analyzing the mathematical knowledge of teachers through a broad conception of the area of mathematical content, meaning these are studies that address aspects of general mathematical content. However, early algebra is addressed as a content area within the study.

In terms of the conceptualization of mathematical knowledge for teaching early algebra, the studies that analyze algebraic thinking or reasoning at a general level do so by solving mathematical problems that require the representation of quantities and modeling through first-order equations [56,64]. Dasch et al. [57] address this content area by exploring activities such as the representation and use of mathematical models to understand algebraic relationships.

Ferreira, Ribeiro, and Ribeiro [65] deal with generalized arithmetic through numerical relationships, the properties of numbers and operations, and the meaning of the equal sign as an equivalence relationship.

Regarding the studies that address the content area linked to functional thinking, for example Gasteiger et al. [69] and Noviyanti and Suryadi [68] focus on pattern identification and representation, while the studies conducted by Wilkie [59,63], Wilkie and Clarke [61], Zapatera and Callejo [66] advance towards the generalization of growth patterns. The studies done by McAuliffe and Lubben [58] and Oliveira, Polo-Blanco, and Henríquez [71] address the generalization of functional relationships, the relationship and interpretation of independent and dependent variables.

Finally, an in-depth analysis of relational thinking is reflected in the studies of Trivilin and Ribeiro [60], Souza, Ribeiro, and Pazuch [70] and Souza, Pazuch, and Ribeiro [72] through the meanings of the equal sign (operational, equivalence and relational).

By contrast, if we look at the research methods used to investigate the mathematical knowledge of teachers involving early algebra, we see that these are largely related to the number of participants. In general terms, when comparing the studies, two different types of research are evident: that conducted on a larger scale that mainly prioritizes the use of questionnaires, and that carried out on a smaller scale that normally uses surveys, interviews, class observation and meetings to ascertain the MKT.

Table 3 shows a predominance of studies that rely on questionnaires. The research where teachers collaborate for professional learning is more situated in this type of data collection instrument, through the items and questions posed to teachers. This last method places the educators in a context of teaching various content areas of early algebra with the purpose of demonstrating and describing the components of mathematical knowledge that they reveal through their answers, either when solving mathematical tasks, interpreting student output or making decisions in teaching situations.

\subsection{Key Findings}

As mentioned in Section 4.1, a large number of the studies analyzed (more than threequarters) are aimed at understanding the MKT for a specific area of algebraic content. As a whole, these studies declare that the teachers, both in early childhood and primary education, exhibit a lack of mastery of mathematical knowledge to teach early algebra. There are limitations in the pedagogical knowledge of the content (for example, the difficulty that teachers have helping students shift from focusing solely on the number pattern to focusing simultaneously on the function (e.g., [58])), and provide examples of learning experiences based on the development of functional thinking that is suitable for students (e.g., [59]).

Other studies reveal the limitations in the knowledge of the content, such as the recognition of the different mathematical meanings of the equal sign (e.g., [60]); solving algebraic tasks mainly by trial and error, not paying attention to the structure of the problem and the knowledge involved in developing algebraic thinking (e.g., [64]); difficulties solving 
problems involving the generalization of patterns related to the discrimination of strategies in the use of proportionality, explanation of a growth pattern and obtaining a general rule (e.g., [66,68]); ignorance of the central issues that the characterization of and working with algebraic thinking imply, such as solving mathematical problems that require the representation of unknown quantities (e.g., [56]) and the case of the generalization of arithmetic with the properties of numbers, the operations and the meaning of the equal sign as equivalence (e.g., [65]); and a lack of strategies for generalizing functional relationships, and problems understanding and connecting the different representations of functions (e.g., [71]).

However, some studies report notable progress in the development of mathematical knowledge including improved relational thinking with the resignification by teachers of the equal sign, moving from the operational to the equivalence and the relational [70], understanding the meaning of the equivalence of the equal sign [72], and increased knowledge related to functional thinking, when transitioning from a written description to a symbolic expression of an explicit generalization [63].

Moreover, fewer than a quarter of the studies investigate professional development and its effect on teaching practice based on the MKT for early algebra showing a relevant increase in the knowledge of pedagogical content and teaching practices related to early algebra, although this does not translate into considerable differences in student performance (e.g., [57]). Heck et al. [67] reveal that teachers achieve a more sophisticated understanding of ways to use context to engage students with ideas in early algebra. Another result of note corresponds to the study proposed by Wilkie and Clarke [61], where the teachers' lack of mastery of mathematical knowledge to address the development of functional thinking leads to discomfort when the students pose questions during a class. The study proposed by Kosko [62] shows that teachers who select probing questions tend to have greater mathematical knowledge or a greater willingness to support student autonomy, but not both.

Finally, in the study proposed for developing an instrument to measure the mathematical knowledge of early childhood education teachers, and more specifically, pedagogical knowledge [69], we will refer only to the results of the items related to early algebraic knowledge. The application of the instrument reveals the teachers' misunderstanding of the mathematical term 'regular pattern', leading to erroneous situations in the context of teaching experiences.

\section{Final Considerations}

This study conducted a systematic review of the way in which the scientific literature produced between 2010 and 2021 in English, Spanish, and Portuguese has conceptualized and empirically studied the mathematical knowledge that early childhood and primary education teachers have of early algebra, from the perspective of the mathematical knowledge for teaching (MKT) model.

We conducted a systematic search of two databases, Web of Science and Scopus, which yielded a total of 17 research articles that we included in our analysis.

Our review of the research articles shows the great advances in recent years in the conceptualization of MKT, for both teachers pre-service and in service, for teaching this content block. However, we agree with Doerr [73] on "the lack of a substantial body of research on teachers' knowledge and practice in the teaching of algebra" (p. 268).

As concerns the conceptualization of mathematical knowledge, we see that while most of the studies focus on understanding the MKT that is demonstrated when teaching a specific area of algebraic content, only a few studies have addressed the relationship between the mathematical knowledge that teachers have in these content areas and the learning outcomes or interactions with students.

Also, of note is the fact that the experiments in the studies involved mostly primary education teachers, which makes it imperative to conduct empirical studies that involve early 
childhood education teachers, whether pre-service or in service, given their importance in the development of early algebra from the earliest ages of schooling [26].

Another important aspect to underscore in the conceptualization of the MKT is that the studies, by investigating areas of specific knowledge of early algebra, focused on the development of functional thinking. In the context of early childhood education, for example, teachers are only placed in content areas that involve functional thinking, more specifically, patterns. However, other elements that support the development of algebraic thinking in this school stage are neglected, such as establishing relationships (selecting, classifying, ordering) by recognizing object attributes, using concrete, pictorial and verbal representations to analyze situations, and analyzing change in diverse contexts [15]. Regarding primary education teachers, while the researchers made an effort to address all areas of algebraic content, there are still few studies that delve into the generalization of arithmetic. Therefore, we consider it important to conduct studies that investigate these content areas.

Our systematic review shows that the studies can be used to investigate, in different levels of detail, the mathematical knowledge and the classroom instruction of the teachers for teaching early algebra, with specialized content knowledge (SCK) being addressed the most in the studies.

The main conclusions found in the analysis of the studies show similarities with respect to the difficulties that teachers exhibit when tackling tasks of an algebraic nature that were identified in other systematic reviews (e.g., [28]).

The results of the systematic review are relevant in the context of teacher training and mathematics education, since they provide an expanded and updated perspective of how the MKT for early algebra has developed, and they identify the challenges that must be addressed by training programs in the future, such as delving into content areas that promote algebraic thinking and the development of adequate mathematical knowledge to implement teaching practices that achieve effective learning of early algebra, since there are still few studies that provide these guidelines [74].

We conclude that a greater number of empirical studies is needed that address the mathematical knowledge of early childhood and primary education teachers for teaching early algebra. These studies need to expand their scope to consider not only the MKT, but also the impact on professional development and teaching practice.

Regarding the limitations of the research, they are related to the bias that could be caused by the selection criteria used to constrain the data set of our study. More specifically, it is possible that by excluding book chapters and conference proceedings, some research documents that may be relevant have not been considered. In addition, the search terms that had to appear in the title, abstract and/or keywords, and the language could also lead to the suppression of some relevant studies that address the mathematical knowledge of teachers involving early algebra. Thus, in the future, it will be necessary to design new systematic reviews that expand both the nature of the documents analyzed and the languages of publication in order to more precisely refine the data obtained so far.

Author Contributions: Conceptualization, N.P. and Á.A.; methodology, N.P.; investigation, N.P.; data analysis, N.P.; writing original draft, N.P.; review and editing, Á.A.; supervision, Á.A. All authors have read and agreed the published version of the manuscript.

Funding: This research has received external funding from the Department of Subject-Specific Didactics and the Institute of Educational Research (IRE) of the University of Girona.

Institutional Review Board Statement: Not applicable.

Informed Consent Statement: Not applicable.

Data Availability Statement: Not applicable.

Acknowledgments: This research was supported by the National Agency for Research and Development of the Government of Chile (ANID) through a PhD scholarship abroad, Folio No. 72200447. 
Conflicts of Interest: The authors declare no conflict of interest.

\section{References}

1. Ponte, J.P. Studying mathematics teachers' knowledge and professional development. In Theory, Critique and Practice of Mathematics Education; Planas, N., Ed.; Graó: Barcelona, España, 2012; pp. 83-98.

2. Llinares, S. Research agendas in mathematics education in Spain. An approach from "ISI-web of knowledge" and ERIH. In Research in Mathematics Education XII; Luengo, R., Gómez, B., Camacho, M., Blanco, L.J., Eds.; SEIEM: Badajoz, España, 2008; pp. 25-54.

3. Barrantes, M.; Blanco, L.J.; Scherer, P.; Steinbring, H. A Study of Prospective Primary Teachers' Conceptions of Teaching and Learning School Geometry. J. Math. Teach. Educ. 2006, 9, 411-436. [CrossRef]

4. Escudero, I.; Sánchez, V. A Mathematics Teachers' Perspective and its Relationship to Practice. Int. J. Sci. Math. Educ. 2007, 6, 87-106. [CrossRef]

5. Cohen, D.K.; Hill, H.C. Learning Policy; Yale University Press: New Haven, CT, USA, 2001.

6. Lane, K.L.; Oakes, W.P.; Powers, L.; Diebold, T.; Germer, K.; Common, E.A.; Brunsting, N. Improving Teachers' Knowledge of Functional Assessment-based Interventions: Outcomes of a Professional Development Series. Educ. Treat. Child. 2015, 38, 93-120. [CrossRef]

7. Chapman, O. Overall Commentary: Understanding and Changing Mathematics Teachers. Res. Trends Math. Teach. Educ. 2014, 295-309. [CrossRef]

8. Hill, H.C.; Rowan, B.; Ball, D.L. Effects of Teachers' Mathematical Knowledge for Teaching on Student Achievement. Am. Educ. Res. J. 2005, 42, 371-406. [CrossRef]

9. Van Dooren, W.; Verschaffel, L.; Onghena, P. The Impact of Preservice Teachers' Content Knowledge on Their Evaluation of Students' Strategies for Solving Arithmetic and Algebra Word Problems. J. Res. Math. Educ. 2002, 33, 319. [CrossRef]

10. Adaptation of the Test Developed to Measure Mathematical Knowledge of Teaching Geometry in Turkey. Int. J. Educ. Methodol. 2019, 5. [CrossRef]

11. Ponte, J.P.; Chapman, O. Prospective mathematics teachers' learning and knowledge for teaching. In Handbook of International Research in Mathematics Education, 3rd ed.; English, L., Kirshner, D., Eds.; Taylor \& Francis: New York, NY, USA, 2015 ; pp. 275-296.

12. Ball, D.L.; Thames, M.H.; Phelps, G. Content Knowledge for Teaching. J. Teach. Educ. 2008, 59, 389-407. [CrossRef]

13. Hill, H.C.; Ball, D.L.; Schilling, S.G. Unpacking pedagogical content knowledge: Conceptualizing and measuring teachers' topic-specific knowledge of students. J. Res. Math. Educ. 2008, 39, 372-400. [CrossRef]

14. Australian Curriculum, Assessment and Reporting Authority [ACARA]. The Australian Curriculum: Mathematics. Available online: https: / / www.australiancurriculum.edu.au/f-10-curriculum/mathematics/ (accessed on 22 May 2015).

15. NCTM. Principles and Standards for School Mathematics; The National Council of Teachers of Mathematics: Reston, VA, USA, 2000.

16. Pincheira, N.; Alsina, Á. Towards a characterization of early algebra from the analysis of the contemporary curricula of Early Childhood Education and Primary Education. Educ. Mate 2021, 33, 153-180. [CrossRef]

17. Molina, M. Proposal of a curricular change: Integration of algebraic thinking in elementary education. Proc. Natl. Acad. Sci. USA 2009, 3, 135-156.

18. Cai, J.; Knuth, E. Early algebraization. In A Global Dialogue from Multiple Perspectives; Springer: Berlin, Germany, 2011.

19. Carraher, D.W.; Schliemann, A.D. Early algebra and algebraic reasoning. In Second Handbook of Research on Mathematics Teaching and Learning; Lester, F.K., Ed.; NCTM e IAP: Reston, VA, USA, 2007; pp. 669-705.

20. Kaput, J. Transforming Algebra from an Engine of Inequity to an Engine of Mathematical Power by "Algebrafying" the K-12 Curriculum; National Center for Improving Student Learning and Achievement in Mathematics and Science: Dartmouth, MA, USA, 2000.

21. Lins, R.; Kaput, J. The early development of algebraic reasoning: The current state of the field. In The Future of the Teaching and Learning of Algebra; The 12th ICMI Study; Chick, H., Stacey, K., Vincent, J., Vincent, J., Eds.; The University of Melbourne: Melbourne, Australia, 2004; Volume 1, pp. 47-70.

22. Blanton, M.L.; Stephens, A.; Knuth, E.; Gardiner, A.M.; Isler-Baykal, I.; Kim, J.-S. The Development of Children's Algebraic Thinking: The Impact of a Comprehensive Early Algebra Intervention in Third Grade. J. Res. Math. Educ. 2015, 46, 39-87. [CrossRef]

23. Molina, M.; Castro, E. Third Grade Students' Use of Relational Thinking. Mathematics 2021, 9, 187. [CrossRef]

24. Papic, M.M.; Mulligan, J.T.; Mitchelmore, M.C. Assessing the Development of Preschoolers' Mathematical Patterning. J. Res. Math. Educ. 2011, 42, 237-268. [CrossRef]

25. Radford, L. Embodiment, perception and symbols in the development of early algebraic thinking. In Proceedings of the 35th Conference of the International Group for the Psychology of Mathematics Education Developing Mathematical Thinking, 4th ed.; Ubuz, B., Ed.; PME: Ankara, Turkey, 2011; pp. 17-24.

26. Kieran, C. Research on the learning and teaching of algebra: A broadening of sources of meaning. In Handbook of Research on the Pscyhology of Mathematics Education: Past, Present and Future; Gutiérrez, A., Boero, P., Eds.; Sense Publishers: Rotterdam, The Netherlands, 2006; pp. 11-49.

27. Santagata, R.; Lee, J. Mathematical knowledge for teaching and the mathematical quality of instruction: A study of novice elementary school teachers. J. Math. Teach. Educ. 2019, 24, 33-60. [CrossRef] 
28. Strand, K.; Mills, B. Mathematical content knowledge for teaching elementary mathematics: A focus on algebra. Math. Enth. 2014, $11,385-432$.

29. Shulman, L.S. Those who understand: Knowledge growth in teaching. Educ. Res. 1986, 15, 4-14. [CrossRef]

30. Shulman, L. Knowledge and Teaching: Foundations of the New Reform. Harv. Educ. Rev. 1987, 57, 1-23. [CrossRef]

31. Fennema, E.; Franke, M. Teachers' knowledge and its impact. In Handbook of Research on Mathematics Teaching and Learning; Grouws, D.A., Ed.; Macmillan: New York, NY, USA, 1992; pp. 147-164.

32. Rowland, T.; Huckstep, P.; Thwaites, A. Elementary Teachers' Mathematics Subject Knowledge: The Knowledge Quartet and the Case of Naomi. J. Math. Teach. Educ. 2005, 8, 255-281. [CrossRef]

33. Carrillo-Yañez, J.; Climent, N.; Montes, M.; Contreras, L.C.; Flores-Medrano, E.; Escudero-Ávila, D.; Vasco, D.; Rojas, N.; Flores, P.; Aguilar-González, Á.; et al. The mathematics teacher's specialised knowledge (MTSK) model. Res. Math. Educ. 2018, 20, 236-253. [CrossRef]

34. Nolan, B.; Dempsey, M.; Lovatt, J.; O'Shea, A. Developing mathematical knowledge for teaching (MKT) for pre-service teachers: A study of students' developing thinking in relation to the teaching of mathematics. In Proceedings of the British Society for Research into Learning Mathematics; Adams, G., Ed.; BSRLM: Dublin, Ireland, 2015; pp. 1-6.

35. Blanton, M.; Kaput, J. Characterizing a classroom practice that promotes algebraic reasoning. J. Resear. Math. Educ. 2005, 36, 412-446.

36. Lüken, M.M.; Sauzet, O. Patterning strategies in early childhood: A mixed methods study examining 3- to 5-year-old children's patterning competencies. Math. Think. Learn. 2020, 23, 28-48. [CrossRef]

37. Radford, L. On the development of early algebraic thinking. Proc. Natl. Acad. Sci. USA 2012, 6, 117-133.

38. Rittle-Johnson, B.; Zippert, E.L.; Boice, K.L. The roles of patterning and spatial skills in early mathematics development. Early Child. Res. Q. 2018, 46, 166-178. [CrossRef]

39. Carpenter, T.P.; Franke, M.L.; Levi, L. Thinking Mathematically: Integrating Arithmetic y Algebra in Elementary School; Heinemann: Portsmouth, UK, 2003.

40. Mason, J. Making use of children's powers to produce algebraic thinking. In Algebra in the Early Grades; Kaput, J., Carraher, D.W., Blanton, M.L., Eds.; Routledge: New York, NY, USA, 2008; pp. 57-94.

41. Lee, K.; $\mathrm{Ng}$, S.F.; Bull, R. Learning and solving algebra word problems: The roles of relational skills, arithmetic, and executive functioning. Dev. Psychol. 2018, 54, 1758-1772. [CrossRef]

42. Carraher, D.W.; Martinez, M.V.; Schliemann, A.D. Early algebra and mathematical generalization. ZDM 2007, 40, 3-22. [CrossRef]

43. Papic, M. An Early Mathematical Patterning Assessment: Identifying young Australian Indigenous children's patterning skills. Math. Educ. Res. J. 2015, 27, 519-534. [CrossRef]

44. Mason, J.; Graham, A.; Johnston-Wilder, S. Developing Thinking in Algebra; Sage: London, UK, 2005.

45. Kaput, J. What is algebra? What is algebraic reasoning? In Algebra in the Early Grades; Kaput, J., Carraher, D.W., Blanton, M.L., Eds.; Routledge: New York, NY, USA, 2008; pp. 5-17.

46. Chimoni, M.; Pitta-Pantazi, D.; Christou, C. The impact of two different types of instructional tasks on students' development of early algebraic thinking. J. Stud. Educ. Develop. 2020, 44, 503-552. [CrossRef]

47. Bastable, V.; Schifter, D. Classroom stories: Examples of elementary students engaged in early algebra. In Algebra in the Early Grades; Kaput, J., Carraher, D.W., Blanton, M.L., Eds.; Routledge: New York, NY, USA, 2008; pp. 165-184.

48. Blanton, M.L.; Isler-Baykal, I.; Stroud, R.; Stephens, A.; Knuth, E.; Gardiner, A. Growth in children's understanding of generalizing and representing mathematical structure and relationships. Educ. Stud. Math. 2019, 102, 193-219. [CrossRef]

49. Blanton, M.L.; Kaput, J.J. Functional thinking as a route into algebra in the elementary grades. In Early Algebraization, Advances in Mathematics Education: A Global Dialogue from Multiple Perspective; Cai, J., Knuth, E., Eds.; Springer: Berlin/Heidelberg, Germany, 2011; pp. 5-23.

50. Stephens, M.; Ribeiro, A. Working towards algebra: The importance of relational thinking. Relime 2012, 15, 373-402.

51. Sánchez-Meca, J. How to conduct a systematic review and meta-analysis. Aula Abier. 2010, 38, 53-64.

52. Gough, D.; Thomas, J.; Oliver, S. Clarifying differences between review designs and methods. Syst. Rev. 2012, 1, 28. [CrossRef]

53. Urrútia, G.; Bonfill, X. PRISMA declaration: A proposal to improve the publication of systematic reviews and meta-analyses. Med. Clínic. 2010, 135, 507-511. [CrossRef]

54. Krippendorff, K. Content Analysis. An Introduction to Its Methodology, 3rd ed.; Sage Publications: California, CA, USA, 2013.

55. Miles, M.B.; Huberman, A.M. Qualitative Data Analysis, 2nd ed.; Sage: Thousand Oaks, CA, USA, 1994.

56. Bair, S.L.; Rich, B.S. Characterizing the Development of Specialized Mathematical Content Knowledge for Teaching in Algebraic Reasoning and Number Theory. Math. Think. Learn. 2011, 13, 292-321. [CrossRef]

57. Dash, S.; de Kramer, R.M.; O’Dwyer, L.M.; Masters, J.; Russell, M. Impact of Online Professional Development or Teacher Quality and Student Achievement in Fifth Grade Mathematics. J. Res. Technol. Educ. 2012, 45, 1-26. [CrossRef]

58. McAuliffe, S.; Lubben, F. Perspectives on pre-service teacher knowledge for teaching early algebra. Perspect. Educ. 2013, 31, 155-169.

59. Wilkie, K.J. Upper primary school teachers' mathematical knowledge for teaching functional thinking in algebra. J. Math. Teach. Educ. 2013, 17, 397-428. [CrossRef]

60. Trivilin, L.R.; Ribeiro, A.J. Mathematical knowledge for teaching different meanings of the equal sign: A study carried out with elementary school teachers. Bolema Bole. de Educa. Matemá. 2015, 29, 38-59. [CrossRef] 
61. Wilkie, K.J.; Clarke, D. Pathways to professional growth: Investigating upper primary school teachers' perspectives on learning to teach algebra. Austr. J. Teach. Educ. 2015, 40, 87-118. [CrossRef]

62. Kosko, K.W. Primary teachers' choice of probing questions: Effects of MKT and supporting student autonomy. Inter. Electron. J. Math. Educ. 2016, 11, 991-1012.

63. Wilkie, K.J. Learning to teach upper primary school algebra: Changes to teachers' mathematical knowledge for teaching functional thinking. Math. Educ. Res. J. 2015, 28, 245-275. [CrossRef]

64. Di Bernardo, R.; Carotenuto, G.; Mellone, M.; Ribeiro, M. Prospective teachers' interpretative knowledge on early algebra. Cader. De Pesqui. 2017, 24, 208-222. [CrossRef]

65. Ferreira, M.C.N.; Ribeiro, M.; Ribeiro, A.J. Mathematical knowledge for teaching algebra at early years. Zetetike 2017, 25, 496-514. [CrossRef]

66. Zapatera, A.; Callejo, M.L. Mathematical knowledge and professional noticing of prospective teachers in the context of pattern generalization. Characterization of Profiles. Revis. Complu. De Educa. 2017, 24, 35-38. [CrossRef]

67. Heck, D.J.; Plumley, C.L.; Stylianou, D.A.; Smith, A.A.; Moffett, G. Scaling up innovative learning in mathematics: Exploring the effect of different professional development approaches on teacher knowledge, beliefs, and instructional practice. Educ. Stud. Math. 2019, 102, 319-342. [CrossRef]

68. Noviyanti, M.E.R.Y.; Suryadi, D.I.D.I. Basic Mathematics knowledge of early childhood teachers. J. Eng. Sci. Technol. 2019, 1, 19-27.

69. Gasteiger, H.; Bruns, J.; Benz, C.; Brunner, E.; Sprenger, P. Mathematical pedagogical content knowledge of early childhood teachers: A standardized situation-related measurement approach. ZDM 2019, 52, 193-205. [CrossRef]

70. Barboza, L.C.D.S.; Ribeiro, A.J.; Pazuch, V. Primary School Teacher's Professional Learning: Exploring Different Meanings of the Equals Signal. Acta Sci. 2020, 22, 71-97. [CrossRef]

71. Oliveira, H.; Blanco, I.P.; Henriques, A. Exploring prospective elementary mathematics teachers' knowledge: A focus on functional thinking. J. Math. Educ. 2021, 12, 257-278. [CrossRef]

72. Souza, L.C.B.; Pazuch, V.; Ribeiro, A.J. Tasks for learning teachers who teach mathematics in the elementary school. Zetetike 2021, 29, 1-25. [CrossRef]

73. Doerr, H.M. Teachers' knowledge and the teaching of algebra. In The Future of the Teaching and Learning of Algebra; The 12th ICMI Study; Chick, H., Stacey, K., Vincent, J., Vincent, J., Eds.; The University of Melbourne: Melbourne, Australia, 2004; Volume 1, pp. 267-290.

74. Hohensee, C. Preparing elementary prospective teachers to teach early algebra. J. Math. Teach. Educ. 2015, 20, 231-257. [CrossRef] 